\title{
Training in Social Entrepreneurship to Generate Productive and Human Capacities Lima, Peru in 2020
}

\author{
Patricia Padilla-Vento (1) \\ Universidad Cesar Vallejo, Lima, Peru \\ Email: patriciapadillavento@gmail.com
}

How to cite this paper: Padilla-Vento, P. (2021). Training in Social Entrepreneurship to Generate Productive and Human Capacities Lima, Peru in 2020. Journal of Human Resource and Sustainability Studies, 9, 93-105.

https://doi.org/10.4236/jhrss.2021.91007

Received: January 8, 2021

Accepted: March 12, 2021

Published: March 15, 2021

Copyright (c) 2021 by author(s) and Scientific Research Publishing Inc. This work is licensed under the Creative Commons Attribution International License (CC BY 4.0).

http://creativecommons.org/licenses/by/4.0/

\begin{abstract}
Lima, capital of Peru, has a third of the total population, the current problem is in the unemployed active economic population (EAP) that with the arrival of the COVID-19 pandemic, its percentage increased. In Lima-Peru, there are no studies that demonstrate the importance of training in social entrepreneurship in universities as an alternative solution to the problem, so the research question is: Why is it important to train in entrepreneurship to generate productive capacities and Humanities in Lima Peru 2020? The study is qualitative, so it will focus on studying the variable in order to understand its importance and that can serve as a basis for future research.
\end{abstract}

\section{Keywords}

Training, Social Entrepreneurship, Productive Capacities, Human Capacities

\section{Introduction}

Training in social entrepreneurship in Latin America is in the process of growth, today it is required that universities promote agents that generate change, seeking economic and sustainable solutions to social problems.

Peru, a country located in western South America, has a diversity of landscapes, geographical conditions, gives it a diversity of natural resources, there is also a variety of beliefs and cults, of pre-Hispanic cultures, which are currently preserved, such as payment to the earth, being part of the celebrations in many regions, under the concept of thanking the Pachamama (mother earth) for her eternal generosity. Pre-Columbian art continues since millennia where experiences in fabrics, gourds, wood, stone, gold, silver, ceramics and even clay are expressed. Its folklore is varied, the musical expressions and dances mix genres 
and the indigenous spirit with the Hispanic one. It has places considered world heritage sites such as the Nazca lines, Caral, among others, but the best known in the world is; the Historic Sanctuary of Machu Picchu built on the top of a mountain, an Inca city with temples, palaces, platforms and water channels that show the ability of civilization to build with large blocks of stone, without amalgam, but with great wisdom. The most renowned archaeologists have theories that consider that it was a Sanctuary, a Sacred City or an important political, religious and administrative center (Sebastián \& Arroyo, 2018).

The GEM 2018-2019 magazine, in the executive summary of social evaluations and self-perception towards entrepreneurship in Peru considers; that there will be opportunities to undertake in the last 6 months $56.0 \%$, that there are facilities to start a business $52.6 \%$, that they have the knowledge, skills and experiences necessary to undertake $71.8 \%$, that for them the fear of failure is an obstacle to put $30.2 \%$ start-up (Serida et al., 2020).

So far in 2020, the Institute of Statistics and Informatics (INEI), mentions that by 2019 , more than 6.4 million Peruvians, which corresponds to $20.5 \%$, were in a situation of poverty (Instituto peruano de economía IPE, 2020). While the technical report of the (INEI) Evolution of monetary poverty 2008-2019 technical, showed a slight decrease in monetary poverty (Instituto Nacional de Estadística e Informática, 2020a), with the arrival of the COVID-19 pandemic, the percentage of poverty increased, seriously affecting its economy. Due to strict generalized quarantine, it led to a decline in GDP of 17.4\% during the first half of 2020 . According to high-frequency World Bank surveys, Peruvian households experienced one of the largest job and income losses in all of Latin America. Given the existing problems, the government has developed a global program of economic compensation and assistance in order to protect the vulnerable population and support companies, which includes cash transfers, postponement of taxes and credit guarantees for the private sector. However, the slowdown in economic activity will produce a substantial increase in monetary poverty, which according to projections will reach levels prior to 2012. Considering the depth of the recession in 2020, a strong rebound is expected for 2021, which presupposes an accelerated execution of public investment and better international conditions as a result of the implementation of a vaccine against COVID-19 (Banco mundial, 2020).

The INEI of Peru, on the occasion of the 485 anniversary of the founding of Lima, announced that according to population estimates and projections for the year 2020, the province of Lima has 9,674,755 inhabitants and represents $29.7 \%$ of the population total of Peru (32,625,948 inhabitants), (Instituto Nacional de Estadística e Informática, INEI, 2020c).

According to the technical report of the INEI, of the Permanent Employment Survey (EPE), carried out in the districts of the province of Lima and the Constitutional Province of Callao. The sample size for the moving quarter September-October-November was 4800 private dwellings, resulting in 1600 monthly dwellings distributed in 400 conglomerates. On March 16 of this year, through 
Supreme Decree No. 044-2020-PCM, the country is declared in a State of Emergency due to the COVID-19 pandemic, establishing a mandatory quarantine and physical distancing, until June 30. In this context, the INEI, in order to guarantee the production of statistical information, and thus satisfy the demand for programmed information, changed the modality of recording information from interviews with home visits (face-to-face interviews) to telephone interviews (Instituto Nacional de Estadística e Informática, 2020b).

Working-age population (PET) according to activity condition; it is that of 14 and more years of age that, being of productive age, is potentially a job seeker (Instituto Nacional de Estadística e Informática, 2020b), as shown in Figure 1.

In the moving quarter September-October-November 2020, there were 7 million 945 thousand 800 people in Metropolitan Lima of age to carry out an economic activity (PET), who constitute the population potentially demanding employment. The PET is composed of the Economically Active Population (EAP), which represents $61.4 \%$ (4 million 881 thousand people) and by the Economically Inactive Population (No EAP) which is equivalent to $38.6 \%$ (3 million 64 thousand 800 people).

In the case of the: Working-age population according to activity condition

Behavior of the labor market indicators the economically active population (EAP) or workforce is made up of people who are employed and those who seek to be. In the quarter of analysis, the EAP represented $61.4 \%$ (4 million 881 thousand) of the working-age population. Compared with the same quarter of the previous year, it decreased by $7.9 \%$, which is equivalent to 415,900 people. Employed economically active population in the quarter of analysis, there were 4 million 142 thousand 700 people with employment in Metropolitan Lima, which represents $84.9 \%$ of the EAP.

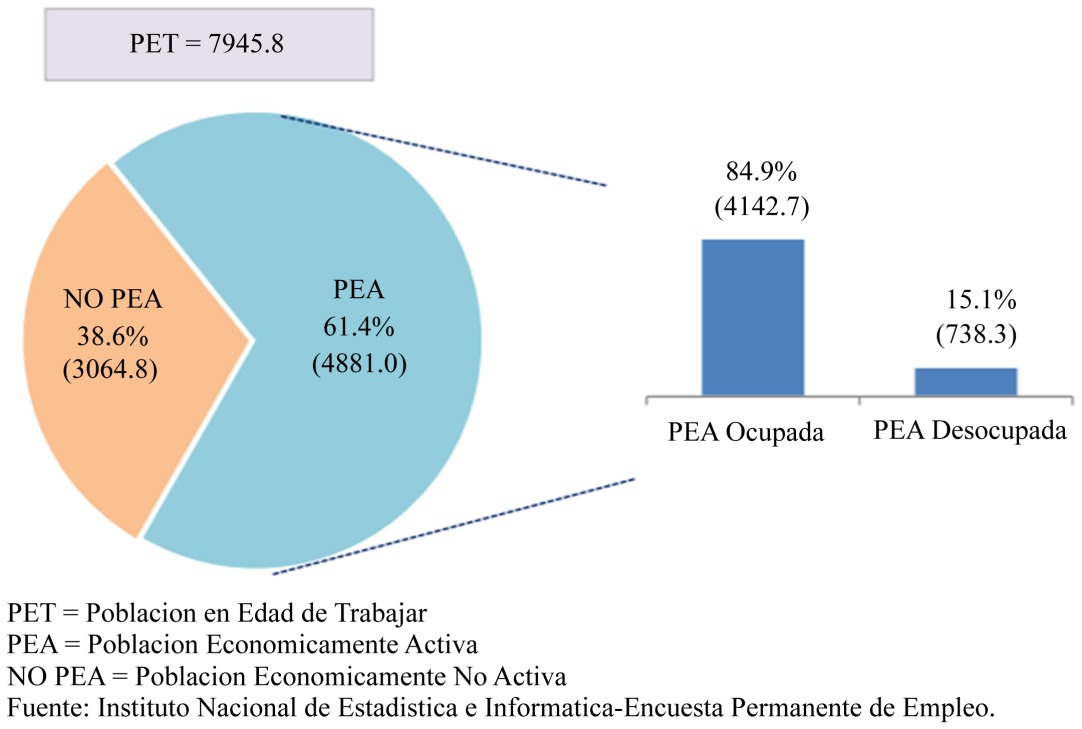

Figure 1. Metropolitan Lima of working age according to activity condition, mobile quarterly: September-October-November 2020 (Thousands of people and percentage). National Institute of Statistics and Informatics, 2020a. 
Economically active unemployed population it is one that actively seeks a job, in the quarter of analysis it amounted to 738 thousand 300 people, and represents $15.1 \%$ of the EAP. Economically inactive population $38.6 \%$ (3 million 64 thousand 800 ) of the working-age population is the economically inactive population (No EAP), compared to the same quarter of the previous year, increased by 20.4\% (518,800), as presented in Figure 2.

On top of that, Behavior of the economically active population (EAP)

By sex in the quarter of analysis, the female EAP decreased by $11.7 \%$ and the male by $4.6 \%$, which is equivalent in absolute figures to 286,600 women and 129,300 men. $55.5 \%$ ( 2 million 706 thousand 900) of the Metropolitan EAP is made up of men and 44.5\% (2 million 174 thousand 100) women. According to age, the EAP contracted in all age groups; thus, it decreased by $11.0 \%(174,100)$ in adults aged 45 and over, by $7.4 \%(71,000)$ in the group of young people between 14 and 24 years of age, and by $6.2 \%(170,900)$ in the $25-44$ age group. $18.3 \%$ of the EAP are between 14 and 24 years old, $52.8 \%$ are between 25 and 44 years old and $28.9 \%$ are between 45 and over. According to the level of education, the EAP decreased at all educational levels; thus, among those with primary education or a lower educational level it fell by $21.4 \%(90,800)$, in the population with a university education by $10.1 \%(137,900)$, in the population with secondary studies, it decreased by $6,8 \%$ (169 thousand 800$)$ and in the group with technical education, 1.8\% (17 thousand 600) (Instituto Nacional de Estadística e Informática, 2020b), as shown in Figure 3.

The following research has been reviewed:

In the book Educate for entrepreneurship, a challenge for the Latin American university mentions that training is transmitting and embodying values to have better human beings (Sebastián \& Arroyo, 2018). It also answers the question: Why train social entrepreneurs? Education assumes the mission of training people willing to undertake actions that solve social and environmental problems through an efficient, sustainable and therefore enduring strategy. He adds that training a new generation of change makers is an unavoidable challenge for Latin American universities (Sebastián \& Arroyo, 2018).

\begin{tabular}{lcccc}
\hline & Septiembre- & Septiembre- & \multicolumn{2}{c}{ Variacion } \\
\cline { 4 - 5 } Condicion de actividad & \begin{tabular}{c} 
Octubre- \\
Octubre- \\
\cline { 4 - 5 }
\end{tabular} & $\begin{array}{c}\text { Noviembre } \\
\text { Noviembre }\end{array}$ & $\begin{array}{c}\text { Absoluta } \\
\text { (Miles) }\end{array}$ & $\begin{array}{c}\text { Porcenual } \\
(\%)\end{array}$ \\
\hline Total de poblacion en edad de trabajar (PET) & 7843.0 & 7945.8 & 102.8 & 1.3 \\
Poblacion economicamente activa (PEA) & 5296.9 & 4881.0 & -415.9 & -7.9 \\
$\quad$ Ocupada & 4961.9 & 4142.7 & -819.2 & -16.5 \\
$\quad$ Desocupada & 335.1 & 738.3 & 403.2 & 120.4 \\
Poblacion económicamente no activa (NO PEA) & 2546.0 & 3064.8 & 518.8 & 20.4 \\
\hline
\end{tabular}

Fuente:Instituto Nacional de Estadistica e Informatica-Encuesta Permanente de Empleo.

Figure 2. Metropolitan Lima in working age according to activity condition, mobile quarterly: September-October-November 2019 AND September-October-November 2020 (Thousands of people, absolute and percentage variation). National Institute of Statistics and Informatics, 2020b. 


\begin{tabular}{lcccc}
\hline & Septiembre- & Septiembre- & \multicolumn{2}{c}{ Variacion } \\
\cline { 5 - 5 } Caracteristicas & $\begin{array}{c}\text { Octubre- } \\
\text { Noviembre } \\
2019\end{array}$ & $\begin{array}{c}\text { Noviembre } \\
2020\end{array}$ & $\begin{array}{c}\text { Absoluta } \\
\text { (Miles) }\end{array}$ & $\begin{array}{c}\text { Porcentual } \\
(\%)\end{array}$ \\
\hline Total & 5296.9 & 4881.0 & -415.9 & -7.9 \\
Sexo & & & & \\
Hombre & 2836.2 & 2706.9 & -129.3 & -4.6 \\
Mujer & 2460.7 & 2174.1 & -286.6 & -11.7 \\
Grupos de edad & & & & \\
De 14 a 24 anos & 964.0 & 893.0 & -71.0 & -7.4 \\
De 25 a 44 anos & 2748.8 & 2577.9 & -170.9 & -6.2 \\
De 45 y mas anos & 1584.2 & 1410.1 & -174.1 & -11.0 \\
Nivel de Educacion & & & & \\
Primaria 1/ & 424.1 & 333.3 & -90.8 & -21.4 \\
Secundaria & 2513.8 & 2344.0 & -169.8 & -6.8 \\
$\quad$ Superior no universitaria & 987.0 & 969.4 & -17.6 & -1.8 \\
Superior universitaria & 1372.1 & 1234.2 & -137.9 & -10.1 \\
\hline
\end{tabular}

1/ Incluye Inicial y Sin nivel.

Fuente:Instituto Nacional de Estadistica e Informatica-Encuesta Permanente de Empleo.

Figure 3. Metropolitan Lima: Economically active population, according to sex, age and level of education achieved, Mobile Quarterly: September-October-November 2019 and September-October-November 2020 (Thousands of people, absolute and percentage variation).

Reviewing various investigations, we found one in the Autonomous University of Mexico that states: The entrepreneur and social entrepreneurship as research topics in Latin America are still in an initial stage, and there is no consensus about their conceptualization, for this reason, the work carried out aims to analyze the concepts that have been spilled about the entrepreneur and social entrepreneurship, in order to serve as a frame of reference for further studies and contribute to a better understanding of this phenomenon. The research method was documentary (Saavedra García et al., 2020). Another research from Mexico whose title is Option for early training in research, experience in the creation of a social entrepreneurship seminar indicates; planning and implementation will contribute to academic and institutional efforts to investigate in a pertinent and open way for the surrounding community. They present a seminar on social entrepreneurship as a training strategy, as an element of attracting human resources for research, where it is intended, through specific training actions, to contribute to the generation of young researchers, so that they can contribute and participate in the project: Development of an educational intervention model for the training of social entrepreneurs in the northern region of the State of Jalisco. Thus, both the thematic components related to the area of social entrepreneurship, as well as those problems and needs that have been covered through this planning and training process, are presented. Together, these training strategies lead to a reflection on the need to incorporate the investigative exercise in an increasingly early and practical way, forming not only through its theoretical components, but especially in the exercise of thinking and dis- 
cussing the way in which we generate knowledge and apply it to the social environment that surrounds us (Marquez Pinedo et al., 2020). Another research from Colombia mentions: Entrepreneurship education fosters an entrepreneurial culture and entrepreneurship, therefore, this chair is mandatory in educational establishments. Colombian universities adopt this guideline, providing education on entrepreneurship, to undertake and innovate, to maintain and develop companies. The type of research is descriptive and explanatory, the analysis of universities committed to entrepreneurship, determining that they teach economic, social, technological and environmental entrepreneurship, promoting internal and external entrepreneurship, with which, their students and graduates have managed to increase productive effectiveness and business creation, contributing to overcoming monetary poverty and human development Marquez (Marquez Pinedo et al., 2020).

In the case of productive capacities, an investigation was found whose objective was to characterize the productive capacity in the economically active population and in a situation of poverty with the lower stratum of the La Ceiba neighborhood of the municipality of Baranoa Atlántico, Colombia, year 2018. The method used was the focus of the theory of productive capacities and the institutional functions of the government in public policies, through the application of surveys and pre-structured interviews, directed to the entire population of 33 heads of each household and their relatives of working age were analyzed the dimension's social aspects such as education, health, physical capacities and competences; economic, productive, financial, technological and commercial. In the results, they found that the few people of working age, who have decided to participate in the training and entrepreneurship strategies of their own business, have managed to improve the economic situation, since they have increased their productive capacities and therefore the well-being of their homes. Concluding that the improvement of economic capacities leads to integral prosperity, and this is derived largely from the generation of economic values, originally represented in financial and economic terms, which are economic profitability, progress, social innovation and accumulation of knowledge in the generation of its own resources (Fernando Escorcia-Marquez et al., 2019).

From the review of Peruvian research found we have:

Kunan points out that currently there is no university or research center focused as a priority on the study of social entrepreneurship. However, some institutions already have courses in the curriculum or publications related to the subject, such as the Pontificia Universidad Católica del Perú, the Universidad del Pacífico, the Universidad Científica del Sur, the Universidad de Ingeniería y Tecnología, the Universidad de Piura, the San Antonio Abad National University of Cusco and the Continental University (Kunan y Universidad Científica del Sur, 2019).

Likewise, in another investigation, they determined that the entrepreneurial intention among university students of administrative sciences and engineering 
careers in Peru; evaluate the influence of the university ecosystem on social entrepreneurial intention, students' self-efficacy, entrepreneurial orientation and the positive perception of the entrepreneur. In addition, the validity of an explanatory model of entrepreneurial intention was evaluated from personal and situational determinants. The sample consisted of 6425 administrative and engineering science students from 24 universities, 14 publics and 10 private, from the coast, mountains and jungle of Peru. Finding that $63 \%$ of students had an intention of social entrepreneurship; No significant differences were found in the sex of the students with respect to the intention of entrepreneurship. Only $3.6 \%$ were participating in a social enterprise. Through these variables (which assume a mediating role), the university ecosystem exerts an indirect influence on self-efficacy and later on entrepreneurial intention. The results are useful to design development models of social entrepreneurship in universities taking into account all the factors reported as important by students and, also, to establish comprehensive plans that consider teaching, practical activities and research in an articulated way, contributing to the increase in the quantity and impact of social enterprises carried out by university students (Risco, Odar, Céspedes, \& Román, 2018).

According to University Law No. 30220, promulgated on July 9, 2014, which included changes in the Peruvian university, we mention three articles that we think are related to our subject, such as: Article 6. Purposes of the university: 6.1 Preserve, enhance and permanently transmit the scientific, technological, cultural and artistic heritage of humanity. 6.2 Train high-quality professionals in a comprehensive manner and with a full sense of social responsibility according to the needs of the country. 6.3 Project its actions and services to the community to promote its change and development. 6.4 Collaborate effectively in the affirmation of democracy, the rule of law and social inclusion. 6.5 Carry out and promote scientific, technological and humanistic research, intellectual and artistic creation. 6.6 Spread universal knowledge for the benefit of humanity. 6.7 Affirm and transmit the diverse cultural identities of the country. 6.8 Promote human and sustainable development at the local, regional, national and global level. 6.9 Serve the community and integral development. 6.10 To form free people in a free society. Article 7. The functions of the university are: 7.1 Professional training. 7.2 Research. 7.3 Cultural extension and social projection. 7.4 Continuing education. 7.5 Contribute to human development. 7.6 The others indicated by the Political Constitution of Peru, the law, its statute and related regulations. Article 48. Research is an essential and mandatory function of the university, which fosters and carries it out, responding through the production of knowledge and development of technologies to the needs of society, with special emphasis on the national reality. Teachers, students and graduates participate in research activity in their own institution or in national or international research networks, created by public or private university institutions (Ministerio de Educación, 2020). 
The Peruvian population has approximately 32 million inhabitants, where a third of the population is in its capital Lima.

The unemployed active economic population (EAP), before the arrival of the COVID-19 pandemic, was already a problem and now the situation is more complicated, with many social problems. In Lima, there are no studies that demonstrate the importance of training in social entrepreneurship in universities as an alternative solution to social problems, so the research question is:

Why is it important to train in social entrepreneurship to generate productive capacities and humanity in Lima Peru 2020?

In addition, it was relevant to formulate the following specific problems:

Why understand the importance of training in social entrepreneurship to improve the behavior of the unemployed EAP by sex in Lima Peru 2020?

Why understand the importance of training in social entrepreneurship to improve the behavior of the unemployed EAP by age in Lima Peru 2020?

Why understand the importance of training in social entrepreneurship to improve the behavior of the unemployed EAP by level of education in Lima Peru 2020 ?

\section{The general objective is:}

Understand the importance of training in social entrepreneurship to generate productive and human capacities in Lima Peru 2020.

The specific objectives were:

Understand the importance of training in social entrepreneurship to improve the behavior of the unemployed EAP by sex in Lima Peru 2020.

Understand the importance of training in social entrepreneurship to improve the behavior of the unemployed EAP by age in Lima Peru 2020.

Understand the importance of training in social entrepreneurship to improve the behavior of the unemployed EAP by level of education in Lima Peru 2020.

\section{Justification.}

It turned out to be justifiable theoretically and practically. Theoretical has the purpose of providing knowledge to understand the importance of training in social entrepreneurship, of which little is known and there is very little information, and the practical justification is that the research, in addition to serving as the basis for future research, is can promote the creation of social enterprises.

\section{Method}

\section{Type of Study and Research}

The methodology is qualitative because the purpose is to understand the training in social entrepreneurship to generate productive and human capacities in Lima Peru 2020, because it is very little known and there are few investigations in this regard, the investigation will serve as the basis for future investigations. For the development an exhaustive search of scientific articles was carried out in indexed journals, books (no Peruvian books of social entrepreneurship), information from the Peruvian Institute of Economics, the National Institute of Statistics 
and Informatics of Peru, World Bank.

\section{Results}

From the analysis of the research, the following discussion of results is carried out:

In the moving quarter September-October-November 2020, in Lima 7 million 945 thousand 800 people were old enough to carry out an economic activity of which $61.4 \%$ (4 million 881 thousand) represents the working-age population (EAP) and 38.6\% (3 million 64 thousand 800 ) are economically inactive population (No EAP). Compared with the same quarter of the previous year, the EAP decreased by $7.9 \%$, which is equivalent to 415 thousand 900 people and the NO EAP increased by $20.4 \%$ (518 thousand 800 ) respectively. Of the total EAP of 4 million 881 thousand, the active employed EAP was 4 million 142 thousand 700 people with employment, which represents $84.9 \%$ and the unemployed EAP is that which actively seeks a job, amounted to 738 thousand 300 people which represents 15.1\% (Instituto Nacional de Estadística e Informática, 2020b).

We consider that an option to improve the decrease and increase of the PEA and NOT the PEA is advisable to train a new generation of change makers is an unavoidable challenge for the Latin American university, as indicated in the text Training in social entrepreneurship, a challenge for the Latin American university (Sebastián \& Arroyo, 2018). Likewise, since social entrepreneurship issues in Latin America are still in an initial stage (Saavedra García et al., 2020). We consider that the challenge for universities is to train in social entrepreneurship.

In Peru, Social Entrepreneurship is little researched, but the review found: Social Entrepreneurship Are universities fulfilling their promoting role? points out that the results of the research are useful to design models of development of social enterprises in the universities taking into account all the factors reported as important by the students and, also, to establish comprehensive plans that consider teaching, practical activities in an articulated way and research contributing to the increase in the quantity and impact of social enterprises carried out by university students (Risco et al., 2018).

Also, in the Colombian Research Higher Education in Entrepreneurship and Overcoming Poverty, mentions that the analysis of universities committed to entrepreneurship, which teach economic, social, technological and environmental entrepreneurship, promoting internal and external entrepreneurship, their students and Graduates have managed to increase the productive effectiveness and the creation of companies, contributing to the overcoming of monetary poverty and to their human development (Pérez Sáenz, 2017).

Likewise, in the research Characterization of productive capacities in the active economic population of the La Ceiba neighborhood of Baranoa, Atlántico, 2018 , it comes to the conclusion that the improvement of economic capacities leads to integral prosperity, and this is largely derived from of the generation of economic values, originally represented in financial and economic terms, which 
are economic profitability, progress, social innovation and accumulation of knowledge in the generation of their own resources (Fernando Escorcia-Marquez et al., 2019).

It is important to understand that training in social entrepreneurship to generate productive and human capacities, because in Lima Peru, social entrepreneurship is in an initial stage, there is also little research, so it is important that the universities promote training in entrepreneurship social to generate productive and human capacities that lead to prosperity by generating economic values in order to contribute to overcoming poverty and human development of the country, following some models of Latin American countries that go a little further as Mexico and Colombia for its planning and implementation, as well as the research carried out in Latin America, since there have been indications that the analysis of universities committed to economic and social entrepreneurship has managed to increase productivity effectiveness and the creation of companies, contributing to overcoming poverty monetary and human development of these.

Is it important to train in social entrepreneurship to improve the behavior of the unemployed EAP in Lima Peru 2020?

From the analysis of the behavior of the PEA we have:

By sex in the quarter of analysis, the female EAP decreased by $11.7 \%$ and the male by $4.6 \%$, which is equivalent in absolute figures to 286,600 women and 129,300 men. $55.5 \%$ (2 million 706 thousand 900) of the Metropolitan EAP is made up of men and $44.5 \%$ ( 2 million 174 thousand 100) women. It is important to know this behavior in order to define the areas where social entrepreneurship can be directed. Likewise, in this regard, it can be contrasted with the Peruvian Research Social Entrepreneurship Are universities fulfilling their promotional role? He points out that: there is a large percentage of intention for social entrepreneurship, but only $3.6 \%$ were participating in a social entrepreneurship, in the case of generating social entrepreneurship it is important to take into account the female and male population, determining the skills and developing them (Kunan y Universidad Científica del Sur, 2019).

By age, the EAP contracted in all groups; Thus, it decreased by $11.0 \%(174,100)$ in adults aged 45 and over, by $7.4 \%(71,000)$ in the group of young people between 14 and 24 years of age, and by $6.2 \%(170,900)$ in the $25-44$ age group. $18.3 \%$ of the EAP are between 14 and 24 years old, $52.8 \%$ are between 25 and 44 years old and $28.9 \%$ are between 45 and over.

It is essential to know the groups and behaviors according to age in order to carry out adequate training in social entrepreneurship. Likewise, we consider that, if one begins to train in social entrepreneurship at an earlier age, it will be better, since in this way the economically active population in the other groups will increase, considering the early age of 14 to 24 years, it is thus that the Universities should promote training in social entrepreneurship through research for those who are starting their studies, and social entrepreneurship should be aimed at young people of school age who are close to completing high school. In The Research Option for early research training, experience in creating a social 
entrepreneurship seminar points out, planning and implementation will contribute to academic and institutional efforts to research in a relevant way. They present a seminar as a training strategy and an element for attracting human resources for research, where it is intended, through specific training actions, to contribute to the generation of young researchers, so that they can contribute and participate in the project: Development of an intervention model educational for the training of social entrepreneurs. Together, these training strategies lead to a reflection on the need to incorporate investigative exercise in an increasingly early and practical way (Marquez Pinedo et al., 2020).

According to the level of education, the EAP decreased at all educational levels; thus, among those with primary education or a lower educational level it fell by $21.4 \%(90,800)$, in the population with a university education by $10.1 \%$ $(137,900)$, in the population with secondary studies it decreased by $6,8 \%(169$ thousand 800 ) and in the group with technical education, 1.8\% (17 thousand 600) (Instituto Nacional de Estadística e Informática, 2020b).

Kunan points out that currently there is no university or research center focused as a priority on the study of social entrepreneurship. However, some institutions already have courses in the curriculum or publications related to the subject (Kunan y Universidad Científica del Sur, 2019).

It is recommended that the universities promote training in social entrepreneurship, to contribute to the development of our country from the universities, as well as put into action what is indicated in the new university law that seeks the quality of education with a humanistic sense.

\section{Conclusion}

We reached the following conclusions:

It is necessary to know the importance of training in social entrepreneurship to generate productive and human capacities in Lima Peru 2020, first because it is in an initial stage but is in the process of growth and why, due to the arrival of COVID-19, the problems already existing were increased. Knowing the movement of the PEA and the NO PEA will allow social enterprises to be directed to different sectors, taking into account research with some models to establish plans that integrate teaching, practices and research from the countries that are ahead of us. Research shows that universities committed to economic and social entrepreneurship have managed to increase productive effectiveness and business creation, contributing to overcoming monetary poverty and human development.

Understanding the importance of training in social entrepreneurship to improve the behavior of the unemployed EAP in Lima Peru 2020 contributes positively to improving the behavior of the EAP, according to sex, age and level of education achieved:

The increase or decrease leads us to know the behavior in order to define the areas where social entrepreneurship can be directed, in Peru there is a large percentage of intention for social entrepreneurship, but the percentage that partici- 
pates in social entrepreneurship is minimal, so Universities must promote their development and take into account the female and male population, determining skills and developing them.

Regarding age, it is essential to know the groups and behaviors for adequate training, followed by planning and implementation so that they participate in social entrepreneurship projects through research, so universities must promote training in entrepreneurship social service to students who are starting their studies, directing entrepreneurship to young people who are about to finish high school.

According to level of education, the EAP decreased at all educational levels, in Peru there is no university or research center focused as a priority on the study of social entrepreneurship, but there are some institutions that already have courses in the curriculum or publications related to the subject, but it is in the process of growth.

It is recommended that universities promote training in social entrepreneurship, to contribute to the development of our country, as well as put into action what is indicated in the new university law that seeks quality of education with a humanistic sense.

\section{Conflicts of Interest}

The author declares no conflicts of interest regarding the publication of this paper.

\section{References}

Banco Mundial (2020). Perú panorama general. https://www.bancomundial.org/es/country/peru/overview

Fernando Escorcia-Marquez, L. et al. (2019). Caracterización de las capacidades productivas en la población económica activa del barrio La Ceiba de Baranoa, Atlántico, 2018. Desarrollo Gerencial, 11, 1-22. https://doi.org/10.17081/dege.11.2.3433 http://search.ebscohost.com/login.aspx?direct=true\&db=fap\&AN=139982941\&lang=es \&site $=$ eds-live \&scope $=$ site

Instituto Nacional de Estadística e Informática (2020a). Evolución de la pobreza monetaria 2018-2019. Informe Técnico. Perú.

https://www.inei.gob.pe/media/cifras_de_pobreza/informe_pobreza2019.pdf

Instituto Nacional de Estadística e Informática (2020b). Situation del Mercado Laboral en Lima Metropolitana.

https://www.inei.gob.pe/media/MenuRecursivo/boletines/12-informe-tecnico-mercado -laboral-set-oct-nov-2020.pdf

Instituto Nacional de Estadística e Informática (INEI) (2020c). La población de Lima supera los nueve millones y medio de habitantes.

http://m.inei.gob.pe/prensa/noticias/la-poblacion-de-lima-supera-los-nueve-millones-y -medio-de-habitantes-12031

Instituto peruano de economía IPE (2020). Regiones más pobres, 19 de febrero del 2020. https://www.ipe.org.pe/portal/regiones-mas-pobres

Kunan y Universidad Científica del Sur (2019). Reporte sobre el estado del emprendimiento social y ambiental en el Perú (p. 16). 
https://drive.google.com/file/d/1UjpZqJ5aKNz9o3Ij915xbdKiKNDn-C2M/view

Marquez Pinedo, M. et al. (2020). Opción Para La Formación Temprana en Investigación, Experiencia en La Creación De Un Seminario De Emprendimiento Social. 3C Empresa, 9, 41-65. https://doi.org/10.17993/3cemp.2020.090141.41-65

http://search.ebscohost.com/login.aspx?direct=true\&db=fap\&AN=142056617\&lang=es \&site $=$ eds-live $\&$ scope $=$ site

Ministerio de Educación (2020). Ley universitaria peruana. http://www.minedu.gob.pe/reforma-universitaria/pdf/ley_universitaria.pdf

National Institute of Statistics and Informatics (2020a). Metropolitan Lima of Working Age According to Activity Condition, Mobile Quarterly: September-October-November 2020 (Thousands of People and Percentage). Figure 1.

https://www.inei.gob.pe/media/MenuRecursivo/boletines/12-informe-tecnico-mercado -laboral-set-oct-nov-2020.pdf

National Institute of Statistics and Informatics (2020b). Metropolitan Lima in Working Age According to Activity Condition, Mobile Quarterly: September-October-November 2019 and September-October-November 2020 (Thousands of People, Absolute and Percentage Variation). Figure 2.

https://www.inei.gob.pe/media/MenuRecursivo/boletines/12-informe-tecnico-mercado -laboral-set-oct-nov-2020.pdf

Pérez Sáenz, R. (2017). Educación Superior en Emprendimiento y la Superación de la Pobreza. Ojas Ablas, 14, 93-106. https://doi.org/10.29151/hojasyhablas.n14a7

Risco, A., Odar, D., Céspedes, C., \& Román, C. (2018). Emprendimiento Social Las universidades, están cumpliendo su rol promotor? Fondo Editorial Universidad San Martin de Porras (pp. 21-22).

https://www.administracion.usmp.edu.pe/investigacion/files/LIBRO-DIGITAL-EMPR ENDIMIENTO-SOCIAL-FINAL-CON-isbn-Y-CB-28-NOVIEMBRE.pdf

Saavedra García, M. L., Camarena Adame, M. E., \& Vargas Sáenz, M. E. (2020). Una aproximación a los conceptos de emprendedor y emprendimiento social. Revista Universidad y Empresa, 22, 1-27.

Sebastián, L., \& Arroyo, I. (2018). Educar para el emprendimiento social, reto para la universidad latinoamericana (Apartado 7 Evidencias sobre la formación de emprendedores sociales en Perú) (pp. 213-227).

http://publishing.fca.unam.mx/index.php?id_product=5\&rewrite=educar-para-el-empr endimiento-social\&controller $=$ product

Serida, J., Alzamora, J., Guerrero, C., Borda, A., \& Morales, O. (2020). Global Entrepreneurship Monitor: Perú 2018-2019 (68 p.). Edición no venal.

https://www.esan.edu.pe/publicaciones/2020/05/07/Final_GEM\%202019.pdf 